\title{
GADAI BERAGUANAN EMAS DALAM HUKUM EKONOMI SYARIAH DI INDONESIA
}

\author{
Khairul Arief Romadhan; Muhammad Fahmi Rois \\ Magister Ilmu Hukum Universitas Diponegoro Semarang \\ khairulariefromadhan@gmail.com; fahmirois.berq@gmail.com
}

\begin{abstract}
Abstrak
Lahirnya Undang-undangNomor 7 Tahun 1992 tentang Perbankan, yang mana dalam undang-undang tersebut, bank syariah disebut sebagai bank dengan sistem bagi hasil. Lalu, pada tahun 1998, disahkanlah Undang-undang Nomor 10Tahun 1998 tentang Perubahan atas Undang-undang Nomor 7 Tahun 1992 tentang Perbankan. Dalam undang-undang perubahan tersebut, digunakan istilah bank dengan prinsip syariah. Undang-undang perubahan itu juga mengatur tentang perbankan sistem ganda (dualsystem banking), yaitu konvensional dan syariah. Istilah bank syariah dipertegas lagi dengan lahirnya Undang-undang Nomor21 Tahun 2008 tentang PerbankanSyariah.Gadaisyariah yang merupakan salahsatu Lembaga Keuangan Syariah yang memberikan kemudahan bagimasyarakat untuk memperoleh dana dengan waktu yang cepat,serta gadai syariah dapat juga sebagai tempat untuk berinvestasi dengan berasaskan syariah.
\end{abstract}

Kata kunci:gadai, syariah, emas.

\section{A. Pendahuluan}

Di Indonesia berlaku sistem ekonomi ganda (dualeconomic system), yaitu sistem ekonomi konvensional dan sistem ekonomi syariah. Dua sistem ini bergulir sejak dipraktikkannya sistem perbankan syariah, yaitu ditandai dengan lahirnya Bank Muamalat pada 1991. Kemudian ditindaklanjuti dengan lahirnya UndangUndang No. 7 Tahun1992 tentang Perbankan. Dalam UU Perbankan tersebut, bank syariah disebut sebagai bank dengan sistem bagi hasil. Lalu pada 1998, disahkan UU No. 10Tahun 1998 tentang Perubahan atas UU No. 7 Tahun 1992 tentang Perbankan. Dalam UU Perubahan itu sudah digunakan istilah bank dengan prinsip syariah. UU Perubahan itu juga mengatur tentang perbankan sistem ganda 
(dualsystem banking), yaitu konvensional dan syariah. Istilah bank syariah dipertegas dengan lahirnya UU No. 21 Tahun 2008 tentang Perbankan Syariah. ${ }^{1}$

Selain itu, di Indonesia berkembang pula lembaga keuangan syariah nonbank, yaitu Lembaga Asuransi Syariah, Pasar Modal Syariah, Pegadaian Syariah, DPLK (Dana Pensiun Lembaga Keuangan) Syariah, Koperasi Syariah, Perusahaan dengan Prinsip Syariah, Badan Wakaf, Badan Amil Zakat, dan BMT(BaitulMal watTamwil).

Gadai Syariah sering diidentikkan dengan Rahn yang secara bahasa diartikan al-tsubut wa al-dawam (tetap dan kekal) sebagian Ulama Luhgat memberi arti al-hab (tertahan). ${ }^{2} \quad$ Sedangkan definisi al-rahn menurut istilah yaitu menjadikan suatu benda yang mempunyai nilai harta dalam pandangan syar'a untuk kepercayaan suatu utang, sehingga memungkinkan mengambil seluruh atau sebagaian utang dari benda itu. ${ }^{3}$

Istilah rahn menurut Imam Ibnu Mandur diartikan apa-apa yang diberikan sebagai jaminan atas suatu manfaat barang yang diagunkan. ${ }^{4}$ Dari kalangan Ulama Mazhab Maliki mendefinisikan rahn sebagai "harta yang dijadikan pemiliknya sebagai jaminan hutang yang bersifat mengikat", ulama Mazhab Hanafi mendefinisikannya dengan "menjadikan suatu barang sebagai jaminan terhadap hak (piutang) yang mungkin dijadikan sebagai pembayar hak tersebut, baik seluruhnya maupun sebagiannya“. Ulama Syafii dan Hambali dalam mengartikan rahn dalam arti akad yakni menjadikan materi (barang) sebagai jaminan utang, yang dapat dijadikan pembayar utang apabila orang yang berhutang tidak bisa membayar hutangnya. ${ }^{5}$

Semakin besarnya minat masyarakat akan pembiayaan gadai syariah, maka perbankan syariah yang merupakan salah satu lembaga yang menyediakan produk tersebut harus tetap dikawal agar tidak ada banker yang melakukan penyimpangan

\footnotetext{
${ }^{1}$ http://perpus.fakum.untad.ac.id/info-buku/68-aspek-hukum-lembaga-keuangan-syariah-diindonesia.html

${ }^{2}$ Departemen Agama RI, Al Qur'an dan Terjemahnya, Bandung : CV. Diponegoro, 2003.

${ }^{3}$ Ghufran Sofiyanah, Mengatasi Masalah Dengan Pegadaian Syariah, Jakarta : RENAISAN Anggota IKAPI, 2005.

${ }^{4}$ Ibnn Rusdy, Bidaya al-Mujtahid, alih bahasa Imam Gazali Said, Jakarta: Pustaka Amini, 1991.

${ }^{5}$ Imam al'ama Ibn Mandur, Lisan al-Arab, Beirut: Muassah Tarikh al-Arabi, 1999.
} 
terhadap sistem yang telah ada karena dapat merusak citra perbankan syariah dimata masyarakat. Oleh karena itu, diperlukan pengawasan terhadap penerapan dan pelaksanaan produk pembiayaan ini agar masyarakat yang telah menggunakan produk tersebut semakin yakin dengan prinsip syariah yang telah dijelaskan dan untuk masyarakat yang belum memanfaatkan produk pembiayaan menjadi yakin dan tertarik dengan produk tersebut. Fatwa Dewan Syariah Nasional Majelis Ulama Indonesia merupakan panduan dalam bagi Perbankan Syariah dalam melakukan Operasional kegiatannya dari aspek menghimpun dana dari masyarakat, menyalurkan dana kepada masyarakat dan jasa keuangan lainnya dan akan memberikan kontribusi terhadap pencapaian target pertumbuhan perbankan syariah karena peraturan tersebut merupakan formulasi yang dibuat oleh para pakar ekonomi Syariah (Muhammad, 2010: 395).

Gadai emas adalah produk bank syariah berupa fasilitas pembiayaan dengan cara memberikan utang (qardh) kepada nasabah dengan jaminan emas (perhiasan/lantakan) dalam sebuah akad gadai (rahn). Bank syariah selanjutnya mengambil upah (ujrah, fee) atas jasa penyimpanan/penitipan yang dilakukannya atas emas tersebut berdasarkan akad ijarah (jasa). Jadi, gadai emas merupakan akad rangkap (uqud murakkabah, multi-akad), yaitu gabungan akad rahn dan ijarah. (lihat Fatwa DSN MUI No 26/DSN-MUI/III/2002 tentang gadai emas).Berdasarkan pemaparanlatarbelakang di atas,makamasalah yang timbuladalah:

1. Apakah yang dimaksud dengan gadai syariah?

2. Bagaimanakah penggunakan akad Qardh dan akad Ijarah dengan anggunan emas pada gadai syariah?

\section{B. MetodePenelitian}

Metode pendekatan yang digunakan dalam penelitian ini adalah pendekatan yuridis normatif metode penelitian normatif tersebut disebut juga pengertian doktrinal (doctrinal research) yaitu suatu penelitian yang memusatkan pada analisis hukum baik hukum yang tertulis dalam buku (law in Books) maupun hukum yang diputuskan oleh hakim melalui putusan pengadilan (law is decided 
by the judge through the judicial process). ${ }^{6}$ Penelitian ini dilakukan untuk mengkaji dan menganalisis gadaiemasberagunanemasdalamhokumekonomisyariah Indonesia berdasarkan bahan hukum utama dengan cara menelaah dan menginterpretasikan hal-hal yang bersifat teoritis yang menyangkut asas hukum, konsepsi doktrin dan norma peraturan perundang-undangan yang berkaitan penelitian ini.pendekatan ini dikenal dengan pendekatan kepustakaan yakni dengan mempelajari buku-buku, peraturan perundang-undangan dan dokumen lain yang berhubungan dengan penelitian.

\section{Hasil Penelitian dan Pembahasan}

\section{Gadai Syariah}

Secara umum rahn dikategorikan sebagai akad yang bersifat derma/tabarruk sebab apa yang diberikan penggadai (rahin) kepada penerima gadai (murtahin) tidak ditukar dengan sesuatu. Yang diberikan murtahin kepada rahn adalah uang. Bukan penukar atas barang yang digadaikan. Rahn juga termasuk akad yang bersifat 'ainiyah, yaitu dikatakan sempurna apabila sudah menyerahkan benda yang dijadikan akad, seperti hibah, pinjam meminajam, titipan dan qirad. ${ }^{7}$

Sebagai referensi atau landasan hukum pinjam-meminjam dengan jaminan (borg) adalah firman Allah Swt.

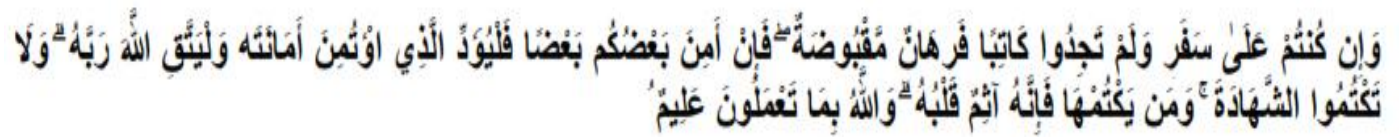

Artinya:Jika kamu dalam perjalanan (dan bermuamalah secara tidak tunai) sedang kamu tidak memperoleh seorang penulis, maka hendaklah ada barang tanggungan yang dipegang ( oleh berpiutang). Akan tetapi jika sebagian kamu mempercayai sebagian yang lain, maka hendaklah yang dipercayai itu

\footnotetext{
${ }^{6}$ Amiruddin dan Zainal Asikin, Pengantar Metode Penelitian Hukum, (Jakarta: Grafiti Press, 2006), Hlm. 118

${ }^{7}$ Hendi Suhendi, Fiqh Muamalah, Cet. 1, (Jakarta: Raja Grafindo Persada, 2002), hlm. 105.
} 
menunaikan amanatnya (hutangnya) dan hendaklah ia bertaqwa kepada Allah Tuhannya (Qs. al-Baqarah: 283).

Menurut Sayyid Sabiq bahwa gadai itu baru dianggap sah apabila memenuhi empat syarat, yaitu: ${ }^{8}$

1. Orangnya sudah dewasa.

2. Berpikiran sehat.

3. Barang yang akan digadaikan sudah ada pada saat terjadi akad gadai dan barang gadaian itu dapat diserahkan/diserahkan kepada penggadai.

4. Barang atau benda yang dapat dijadikan jaminan itu dapat berupa emas, berlian dan benda bergerak lainnya dan dapat pula surat-surat berharga (surat tanah atau surat rumah). ${ }^{9}$

Ketentuan gadai syariah telah diatur dalam ketentuan Dewan Syariah Nasional sebagai berikut: ${ }^{10}$

1. Murtahin (penerima barang) mempunyai hak untuk menahan Marhun (barang) sampai semua utang Rahin (yang menyerahkan barang) dilunasi.

2. Marhun dan manfaatnya tetap menjadi milik Rahin. Pada prinsipnya, Marhun tidak boleh dimanfaatkan oleh Murtahin kecuali seizin Rahin, dengan tidak mengurangi nilai Marhun dan pemanfaatannya itu sekedar pengganti biaya pemeliharaan dan perawatannya.

3. Pemeliharaan dan penyimpanan Marhun pada dasarnya menjadi kewajiban Rahin, namun dapat dilakukan juga oleh Murtahin, sedangkan biaya dan pemeliharaan penyimpanan tetap menjadi kewajiban Rahin.

4. Besar biaya pemeliharaan dan penyimpanan Marhun tidak boleh ditentukan berdasarkan jumlah pinjaman.

5. Penjualan Marhun

a. Apabila jatuh tempo, Murtahin harus memperingatkan Rahin untuk segera melunasi utangnya.

b. Apabila Rahin tetap tidak dapat melunasi utangnya, maka Marhun dijual paksa/dieksekusi melalui lelang sesuai syariah.

\footnotetext{
${ }^{8}$ S. Purnamasari, Ibid.

${ }^{9}$ Ibid, hlm.256

${ }^{10}$ Fatwa DSN No. 25/DSN-MUI/III/2002 Tentang Rahn.
} 
c. Hasil penjualan Marhun digunakan untuk melunasi utang, biaya pemeliharaan dan penyimpanan yang belum dibayar serta biaya penjualan.

d. Kelebihan hasil penjualan menjadi milik Rahin dan kekurangannya menjadi kewajiban Rahin.

Rahn atau pinjaman dengan jaminan suatu benda memiliki beberapa rukun, antara lain yaitu: ${ }^{11}$

1. Akad dan ijab Kabul

2. Aqid, yaitu orang yang menggadaikan (rahin) dan yang menerima gadai (murtahin). Adapun syarat yang ber-akad adalah ahli tasyarruf. ${ }^{12}$

3. Barang yang dijadikan jaminan (borg), syarat pada benda uyang dijadikan jaminan ialah keadaan barang itu tiddak rusak sebelum janji hutang harus dibayar. Rosul bersabda, setiap barang yang boleh diperjual belikan boleh dijadikan barang gadai.

Ada hutang, disyaratkan keadaan hutang telah tetap. Menurut ulama Hanafiyah mensyaratkan marhun, antara lain: ${ }^{13}$

1. Dapat diperjualbelikan

2. Bermanfaat

3. Jelas

4. Milik rahin

5. Bisa diserahkan

6. Tidak bersatu dengan harta lain

7. Dipegang oleh rahin

8. Harta yang tetap atau dapat dipindahkan. ${ }^{14}$

Alasan utama mengapa broker gadai syariah hanya menerima emas adalah untuk menghilangkan unsur gharar yaitu ketidakpastian. Menurut Institute of

\footnotetext{
${ }^{11}$ S. Purnamasari, Upaya-Upaya Pegadaian Syariah Dalam Mengentaskan Praktik Riba, hlm. 5. ${ }^{12}$ yaitu mampu membelanjakan harta dan dalam hal ini memahami persoalan-persoalan yang berkaitan dengan gadai. Menurut ulama Syafi'iyah ahliyah adalah orang yang telah sah untuk jual beli, yakni berakal dam mumayyis, tetapi tidak disyaratkan harus baligh.

${ }^{13}$ S. Purnamasari, Ibid.

${ }^{14} \mathrm{Ibid}$, hlm. 162
} 
Islamic Banking and Insurance (2015), Gharar dilarang oleh Alquran, yang secara eksplisit melarang perdagangan yang dianggap memiliki risiko berlebihan karena ketidakpastian. Bagi penilai yang tidak terlatih nilai agunan seperti jam tangan, batu permata dan berlian dll mungkin berbeda secara luas. Barang-barang ini harus dievaluasi oleh personil terlatih. Emas di sisi lain, memiliki harga standar yang berfluktuasi sesuai harga pasar emas internasional. Harga emas atau perhiasan emas karena itu standar dan ini menghilangkan unsur gharar. ${ }^{15}$

Skema Ar-Rahnu menyediakan produk keuangan untuk pedagang kecil dan kelompok pendapatan rendah yang biasanya memiliki beberapa kesulitan untuk mendapatkan fasilitas tersebut dari sistem keuangan konvensional. Ini adalah sistem pembiayaan berbasis agunan berbasis Islam, diperkenalkan sebagai sumber pembiayaan berbasis syariah dan sumber pembiayaan yang lebih mudah, dengan emas sebagai jaminan dengan imbalan uang tunai. Pialang gadai Islam didasarkan pada empat konsep yaitu Qardhul Hassan (Wajib YadAmanah), Alujrah (amanah), danWadiah Yadhomanah (dijamin dengan jaminan) (Bhatt and Sinnakkannu, 2008). ${ }^{16}$

Pembentukan skema Ar-Rahnu di lembaga perbankan dengan maksud untuk memberikan kepatuhan syariah dan alternatif yang lebih baik dari metode pembiayaan bagi masyarakat Muslim namun tidak dapat dikonsumsi pada tingkat yang baik dari penggunaan karena dua alasan yaitu; Sebuah persepsi bahwa institusi perbankan selalu diasosiasikan untuk mereka yang memiliki uang dan tidak cocok dengan kelompok berpenghasilan rendah dengan hanya sedikit emas sebagai aset gadai; Dan kemungkinan bahwa mereka yang ingin uang cepat mungkin menemukan bahwa mereka tidak memenuhi syarat karena ada kaset merah dalam mendapatkan pembiayaan atau pinjaman dari lembaga-lembaga tersebut (Amin et al, 2007). ${ }^{17}$

\footnotetext{
${ }^{15}$ Nor Zaihan bin Mohd Noar\&Mohd Aminul Islam, A Study On The Efficacy Of Islamic Pawn Broking Services In Fulfilling Socio -Economic Needs: A Case Of Two Cities-Kuantan And Kuala Terengganuin Malaysia.

${ }^{16}$ Mohamad Abd Hamid, Ishak Abd Rahman, \&Ahmad Nafis Abd Halim, Key Factors Influencing Customers to Use Ar-Rahnu (Islamic Pawn Shop) In Malaysia: Evidence from Bank Rakyat, hlm. 74.

${ }^{17}$ Mohamad Abd Hamid, Ishak Abd Rahman, \&Ahmad Nafis Abd Halim, Ibid.
} 


\section{Akada Qard dan akad Ijarah dengan Angggunan Emas pada Gadai Syariah}

\section{a. Akad Qard}

Pembiayaan berdasarkan akad pinjam meminjam ini ditempuh bank dalam keadaan darurat (emergency situation), karena pada prinsipnya melalui pembiayaan berdsarkan akad pinjam meminjam ini bank tidak boleh mengambil keuntungan dari nasabah sedikit pun, kecuali hanya sebatas biaya administrasi yang benar-benar digunakan oleh pihak bank dalam proses pembiayaan. Pembiayaan akad pinjam meminjam dibenarkan menjadi dua, yaitu pembiayaan qardh dan pembiayaan qardh al-hasan. ${ }^{18}$

Ketentua qardh telah diatur dalam fatwa Dewan Syariah Nasional, sebagai berikut: ${ }^{19}$

\section{Pertama: Ketentuan Umum al-Qardh}

1. Al-Qardh adalah pinjaman yang diberikan kepada nasabah (muqtaridh) yang memerlukan.

2. Nasabah al-Qardh wajib mengembalikan jumlah pokok yang diterima pada waktu yang telah disepakati bersama.

3. Biaya administrasi dibebankan kepada nasabah.

4. LKS dapat meminta jaminan kepada nasabah bilamana dipandang perlu.

5. Nasabah al-Qardh dapat memberikan tambahan (sumbangan) dengan sukarela kepada LKS selama tidak diperjanjikan dalam akad.

6. Jika nasabah tidak dapat mengembalikan sebagian atau seluruh kewajibannya pada saat yang telah disepakati dan LKS telah memastikan ketidakmampuannya, LKS dapat:

a. memperpanjang jangka waktu pengembalian, atau

b. menghapus (write off) sebagian atau seluruh kewajibannya.

\section{Kedua: Sanksi}

\footnotetext{
${ }^{18}$ Abdul Ghafur Anshari, Loc. cit. hlm. 23.

${ }^{19}$ Fatwa Dewan Syariah Nasional No. 19/DSN-MUI/IV/2001 tentang Al-Qardh.
} 
1. Dalam hal nasabah tidak menunjukkan keinginan mengembalikan sebagian atau seluruh kewajibannya dan bukan karena ketidak-mampuannya, LKS dapat menjatuhkan sanksi kepada nasabah.

2. Sanksi yang dijatuhkan kepada nasabah sebagaimana dimaksud butir 1 dapat berupa --dan tidak terbatas pada-- penjualan barang jaminan.

3. Jika barang jaminan tidak mencukupi, nasabah tetap harus memenuhi kewajibannya secara penuh.

\section{Ketiga: Sumber Dana}

Dana al-Qardh dapat bersumber dari:

a. Bagian modal LKS;

b. Keuntungan LKS yang disisihkan; dan

c. Lembaga lain atau individu yang mempercayakan penyaluran infaqnya kepada LKS.

\section{Keempat: -}

1. Jika salah satu pihak tidak menunaikan kewajibannya atau jika terjadi perselisihan di antara para pihak, maka penyelesaiannya dilakukan melalui Badan Arbitrasi Syari'ah setelah tidak tercapai kesepakatan melalui musyawarah.

2. Fatwa ini berlaku sejak tanggal ditetapkan dengan ketentuan jika di kemudian hari ternyata terdapat kekeliruan, akan diubah dan disempurnakan sebagaimana mestinya.

\section{b. Akad Ijarah}

Jenis pembiayaan ini diberikan kepada nasabah yang ingin mendapatkan manfaat atas dasar suatu barang tertentu tanpa perlu memiliki. Untuk memenuhi kepentingan nasabah dimaksud, maka pihak bank syariah dapat menyewakan barang yang menjadi objek sewa dan untuk itu pihak bank berhak mendapatkan uang sewa (ujrah) yang besarnya sesuai kesepakatan. Varian dari akad sewamenyewa ini selain berupa pembiayaan ijarah, maka dimungkinkan pihak nasabah untuk memiliki barang yang disewa di akhir masa sewa dengan menggunakan akad opsi melalui mekanisme hibah maupun mekanisme beli. Yang terakhir ini disebut Pembiayaan Ijarah Muntahiya Bit Tamlik (IMBT). 
Dewan Syariah telah mengeluarkan fatwa tentang ijarah yaitu sebagai berikut:

\section{Pertama: Rukun dan Syarat Ijarah}

1. Pernyataan ijab dan qabul.

2. Pihak-pihak yang berakad (berkontrak): terdiri atas pemberian sewa (lessor, pemilik aset, LKS) dan Penyewa (lessee, pihak yang mengambil manfaat dari penggunaan aset, nasabah)

3. Obyek kontrak: pembayaran (sewa) dan manfaat dari penggunaan aset.

4. Manfaat dari penggunaan aset dalam ijarah adalah objek kontrak yang harus dijamin, karena ia rukun yang harus dipenuhi sebagai ganti dari sewa dan bukan aset itu sendiri.

5. Sighat Ijarah adalah berupa pernyataan dari kedua belah pihak yang berkontrak, baik secara verbal atau dalam bentuk lain yang equivalent, dengan cara penawaran dari pemilik aset (LKS) dan penerimaan yang dinyatakan oleh penyewa (nasabah).

\section{Kedua: Ketentua Obyek Ijarah}

1. Obyek ijarah adalah manfaat dari penggunaan barang dan/atau jasa.

2. Manfaat barang atau jasa harus bisa dinilai dan dapat dilaksanakan dalam kontrak.

3. Manfaat barang atau jasa harus yang bersifat dibolehkan (tidak diharamkan).

4. Kesanggupan memenuhi manfaat harus nyata dan sesuai dengan syari'ah.

5. Manfaat harus dikenali secara spesifik sedemikian rupa untuk menghilangkan jahalah (ketidaktahuan) yang akan mengakibatkan sengketa.

6. Spesifikasi manfaat harus dinyatakan dengan jelas, termasuk jangka waktunya. Bisa juga dikenali dengan spesifikasi atau identifikasi fisik.

7. Sewa atau upah adalah sesuatu yang dijanjikan dan dibayar nasabah kepada LKS sebagai pembayaran manfaat. Sesuatu yang dapat dijadikan harga dalam jual beli dapat pula dijadikan sewa atau upah dalam Ijarah.

8. Pembayaran sewa atau upah boleh berbentuk jasa (manfaat lain) dari jenis yang sama dengan obyek kontrak. 
9. Kelenturan (flexibility) dalam menentukan sewa atau upah dapat diwujudkan dalam ukuran waktu, tempat dan jarak.

\section{Ketiga : Kewajiban LKS dan Nasabah dalam Pembiayaan Ijarah}

1. Kewajiban LKS sebagai pemberi manfaat barang atau jasa:

a. Menyediakan barang yang disewakan atau jasa yang diberikan

b. Menanggung biaya pemeliharaan barang.

c. Menjamin bila terdapat cacat pada barang yang disewakan.

2. Kewajiban nasabah sebagai penerima manfaat barang atau jasa:

a. Membayar sewa atau upah dan bertanggung jawab untuk menjaga keutuhan barang serta menggunakannya sesuai kontrak.

b. Menanggung biaya pemeliharaan barang yang sifatnya ringan (tidak materiil).

c. Jika barang yang disewa rusak, bukan karena pelanggaran dari penggunaan yang dibolehkan, juga bukan karena kelalaian pihak penerima manfaat dalam menjaganya, ia tidak bertanggung jawab atas kerusakan tersebut.

\section{Keempat: -}

Jika salah satu pihak tidak menunaikan kewajibannya atau jika terjadi perselisihan di antara para pihak, maka penyelesaiannya dilakukan melalui Badan Arbitrasi Syari'ah setelah tidak tercapai kesepakatan melalui musyawarah.

Dewan Syariah Nasional juga telah mengeluarkan fatwa tentang Ijarah Muntahiya Bit Tamlik, dengan ketentuan sebagai berikut: ${ }^{20}$

\section{Pertama: Ketentuan Umum:}

Akad al-Ijarah al-Muntahiyah bi al-Tamlik boleh dilakukan dengan ketentuan sebagai berikut:

a. Semua rukun dan syarat yang berlaku dalam akad Ijarah (Fatwa DSN nomor: 09/DSN-MUI/IV/2000) berlaku pula dalam akad al-Ijarah al-Muntahiyah bi al-Tamlik.

b. Perjanjian untuk melakukan akad al-Ijarah al-Muntahiyah bi al-Tamlik harus disepakati ketika akad Ijarah ditandatangani.

\footnotetext{
${ }^{20}$ Fatwa DSN Nomor. 27/DSN-MUI/III/2002.
} 
c. Hak dan kewajiban setiap pihak harus dijelaskan dalam akad.

\section{Kedua: Ketentuan tentang al-Ijarah al-Muntahiyah bi al-Tamlik}

1. Pihak yang melakukan al-Ijarah al-Muntahiah bi al-Tamlik harus melaksanakan akad Ijarah terlebih dahulu. Akad pemindahan kepemilikan, baik dengan jual beli atau pemberian, hanya dapat dilakukan setelah masa Ijarah selesai.

2. Janji pemindahan kepemilikan yang disepakati di awal akad Ijarah adalah wa'd, yang hukumnya tidak mengikat. Apabila janji itu ingin dilaksanakan, maka harus ada akad pemindahan kepemilikan yang dilakukan setelah masa Ijarah selesai.

\section{Ketiga: -}

1. Jika salah satu pihak tidak menunaikan kewajibannya atau jika terjadi perselisihan di antara kedua belah pihak, maka penyelesaiannya dilakukan melalui Badan Arbitrasi Syari'ah setelah tidak tercapai kesepakatan melalui musyawarah.

2. Fatwa ini berlaku sejak tanggal ditetapkan dengan ketentuan jika di kemudian hari ternyata terdapat kekeliruan, akan diubah dan disempurnakan sebagaimana mestinya.

Fatwa DSN memang menyebutkan secara terperinci mengenai rukun dan syarat sah dari gadai emas ini adalah harus ada murtahin (penerima gadai), rahin (yang menyerahkan barang), dan marhun (barang yang digadaikan). Gadai Emas di Bank BRI Syariah telah memenuhi rukun dan syarat sah gadai emas sesuai dengan Fatwa DSN yaitu adanya murtahin (Bank BRI Syariah), rahin (Nasabah), dan marhun (barang yang digadaikan berupa perhiasan emas atau emas batangan). Bank BRI Syariah sebagai murtahin sesuai dengan Fatwa DSN, berhak untuk menahan marhun atau barang yang digadaikan berupa emas sampai Nasabah melunasi hutangnya.

Untuk ijab qabul atau perjanjian gadai, dalam implementasi pada Bank BRI Syariah perjanjian tersebut tertuang dalam Sertifikat Gadai Syariah (SGS) dimana akad yang digunakan adalah Akad Pinjaman dengan Gadai (akad qardh) dan Akad Sewa Tempat (akad ijarah). Untuk pemeliharaannya, dalam Fatwa DSN 
No.25/DSN-MUI/III/2002 tentang Rahn disebutkan bahwa pemeliharaan dan penyimpanan marhun pada dasarnya menjadi kewajiban rahin, tetapi dapat dilakukan juga oleh murtahin. Pada praktek Gadai Emas pada Bank BRI Syariah, marhun harus disimpan dan dipelihara secara langsung oleh Bank BRI Syariah. Hal ini dilakukan agar ada jaminan bahwa rahin akan membayar hutangnya tepat waktu. ${ }^{21}$ Prosedur pelelangan barang jaminan jatuh tempo menurut SOP BRI Syariah. Pihak Perusahaan (Bank) diwajibkan untuk menghubungi para nasabah yang sudah jatuh tempo masa pinjamannya minimal 7 hari sebelum jatuh tempo masa pinjamannya.

Setelah perberitahuan jatuh tempo kepada Nasabah dilaksanakan, kepada Nasabah masih diberi kesempatan terakhir untuk menyelesaikannya sampai batas tenggang waktu eksekusi barang jaminan yaitu 4 hari setelah tanggal jatuh tempo. ${ }^{22}$ Metode pelaksanaan lelang memang sudah tercantum dalam SOP Panduan Pelaksanaan Lelang, namun pada realita yang terjadi selama ini Bank BRI Syariah belum pernah melaksanakan lelang tersebut, akan tetapi Bank BRI Syariah langsung mengundang Toko Emas yang ada di Pekanbaru dan langsung menanyakan berapa Toko tersebut berani membeli barang jaminan tersebut, jika harga sudah disepakati maka akan terjadi transaksi jual beli. Transaksi tersebut dilakukan dengan menggunakan telephon. ${ }^{23}$ Menurut ketentuan surat edaran BI No. 14/7/DPbS perihal Produk Qardh Beragun Emas Bagi Bank Syariah dan Unit Usaha Syariah. Bank Syariah atau UUS wajib menjelaskan secara lisan atau tertulis (transparant) kepada nasabah antara lain:

a. karakteristik produk antara lain fitur, risiko, manfaat, biaya, persyaratan, dan penyelesaian apabila terdapat sengketa;

b. hak dan kewajiban nasabah termasuk apabila terjadi eksekusi agunan emas.

Akad yang terkait dengan produk Qardh Beragun Emas yangsudah ada sebelum berlakunya Surat Edaran Bank Indonesia ini dinyatakan tetap berlaku

\footnotetext{
${ }^{21}$ Ahmad Maulidizen, Aplikasi Gadai Emas Syari'ah: Studi Kasus Pada BRI Syari'ah Cabang Pekanbaru.

${ }^{22}$ Mega Pendra (Penaksir Madya Bank BRI Syariah Kantor Cabang Pekanbaru) Wawancara Dengan Ahmad Maulidizen.

${ }^{23}$ Ibid.
} 
sampai dengan jatuh tempo, dan dapat diperpanjang. Pembiayaan Qardh Beragun Emas dapat diberikan palingbanyak sebesar Rp250.000.000,00 (dua ratus lima puluh juta rupiah) untuk setiap nasabah, dengan jangka waktu pembiayaan paling lama 4 (empat) bulan dan dapat diperpanjang paling banyak 2 (dua) kali.Perpanjangan jangka waktu Qardh Beragun Emas yang telahdilakukan oleh Bank Syariah atau UUS sebelum berlakunya Surat Edaran Bank Indonesia ini tidak dihitung sebagaiPerpanjangan.

\section{Penutup}

Dengan jumlah penduduk Indonesia yang banyak dengan mayoritas beragama islam. Produk-produk keuangan yang berbasis syariah sangat berguna, dan menggantikan sistem keuangan konvensional pada masa ini.

Pemerintah telah memberikan pilihan mengenai sistem keuangan kepada masyarakat yaitu sistem keuangan syariah dan sistem keuangan berbasis syariah. Sistem keuangan berbasis syariah terdiri :
a. Bank syariah,
b. Lembaga keuangan mikro syariah,
c. Asuransi syariah,
d. Reasuransi syariah,
e. Reksadana syariah,
f. Obligasi syariah dan surat berharga berjangka menengah syariah,
g. Sekuritas syariah,
h. Pembiayaan syariah,
i. Pegadaian syariah,
j. Dana pensiun lembaga keuangan syariah,
k. Bisnis syariah.

Gadai syariah sebagai salah satu layanan keuangan berbasis syariah yang dimiliki oleh Indonesia harus diperbaiki sistem keuangannya terutama pada penerapan prinsip-prinsip syariah. Karena kondisi dilapangan produk-produk yang dikeluarkan yang mengatasnamakan syariah tapi dalam pelaksanaannya tidak sesuai dengan prinsip syariah. 


\section{Daftar Pustaka}

\section{Buku}

Abdul Ghafur Anshari,2008, Penerapan Prinsip Syariah Dalam Lembaga Keuangan, Lembaga Pembiayaan dan Perusahaan Pembiayaan, Yogyakarta: Pustaka Pelajar, Cet.1.

Mardani, 2014, Hukum Bisnis Syariah, Jakarta: Prenamedia Group.

\section{Jurnal}

Ahmad Maulidizen, Aplikasi Gadai Emas Syari'ah: Studi Kasus Pada BRI Syari'ah Cabang Pekanbaru.

Erie Hariyanto, penyelesaian sengketa ekonomi syariahdi indonesia.

Mohamad Abd Hamid, Ishak Abd Rahman, \& Ahmad Nafis Abd Halim, Key Factors Influencing Customers to Use Ar-Rahnu (Islamic Pawn Shop) In Malaysia: Evidence from Bank Rakyat.

Mohammad Omar Farooq, Qard H asan, Wadi 'ah/Amanah and Bank Deposits: Applications and Misapplications of Some Concepts in Islamic Banking.

S. Purnamasari, Upaya-Upaya Pegadaian Syariah Dalam Mengentaskan Praktik Riba.

Zor Zaihan Bin Mohd Noar and Mohd Aminul Islam, A Study On The Efficacy Of Islamic Pawn Brokingservices In Fulfilling Soci-Economic Needs: A Case Of Two Cities-Kuantan And Kuala Terengganuin Malaysia.

\section{Peraturan Perundang-undangan}

Undang-Undang No. 3 Tahun 2006 tentang Peradilan Agama Undang-Undang No.21 Tahun 2008 tentang Perbankan Syariah

\section{Fatwa}

Fatwa Dewan Syariah No.25/DSN-MUI/III/2002 tanggal 28 Maret 2002 tentang Ar-Rahn Fatwa Dewan Syariah No.26/DSN-MUI/III/2002 tanggal 28 Maret 2002 tentang Rahn Emas 